\title{
The Nature of Carbenicillin Resistance in Pseudomonas aeruginosa
}

\author{
By A. H. THOMAS AND R. A. BROADBRIDGE \\ Division of Biological Standards, National Institute for Medical Research, \\ Mill Hill, London, N.W.7
}

(Accepted for publication 16 October 1971)

\begin{abstract}
SUMMARY
Carbenicillin resistance in two strains of Pseudomonas aeruginosa has been investigated. Pseudomonas aeruginosa NCTC I0490, a carbenicillin sensitive strain, produced a $\beta$-lactamase when grown in the presence of carbenicillin. This enzyme although active against benzylpenicillin did not hydrolyse carbenicillin. Cell walls of $P$. aeruginosa NCTC I0 490 habituated to the presence of carbenicillin showed a higher lipid content compared with the walls of the parent strain. Hospitalisolated, carbenicillin-resistant $P$. aeruginosa $69 / 4992$ synthesized a $\beta$-lactamase which hydrolysed carbenicillin as well as benzylpenicillin. The two types of enzyme were characterized by their substrate profile, sensitivity to enzyme inhibitors and resolution by isoelectric focusing. Enzymes active against carbenicillin were differentiated by isoelectric focusing from those unable to hydrolyse carbenicillin; both types of enzyme were shown to be complex mixtures by this technique.
\end{abstract}

\section{INTRODUCTION}

Carbenicillin (disodium salt of 6 ( $\alpha$-carboxyphenyl acetamido) penicillanic acid) is a semisynthetic penicillin active against Pseudomonas aeruginosa in vitro (Acred et al. 1967; Knudsen, Rolinson \& Sutherland, I967). Because the sensitivities of many strains of $P$. aeruginosa to carbenicillin are within a reasonably narrow range of concentrations which can be safely obtained in vivo, carbenicillin has been used successfully in the treatment of pseudomonal infections (Brumfitt, Percival \& Leigh, 1967; Jones \& Lowbury, 1967; Richardson, Spittle, James \& Robinson, I968; Stratford, I968). The original reports of carbenicillin-resistant strains of $P$. aeruginosa described small colony variants some of which produced $\beta$-lactamase, although none of these strains inactivated carbenicillin (Brumfitt et al. 1967; Jones \& Lowbury, 1967; Smith \& Finland, 1968). Recently an increasing number of carbenicillin-resistant strains of $P$. aeruginosa have been isolated (Stratford, I968; Bell \& Smith, 1969; Darrell \& Waterworth, 1969; Stephenson, 1969; Lowbury et al. 1969; News on, 1969) and the last two reports described strains of $P$. aeruginosa able to inactivate carbenicillin.

In an attempt to understand the mechanism of carbenicillin resistance, both cell wall preparations and $\beta$-lactamase enzyme preparations from carbenicillin-sensitive and carbenicillin-resistant Pseudomonas aeruginosa have been compared.

\section{METHODS}

Materials. The following antibiotics were used: Sodium Benzylpenicillin, Cephaloridine (Glaxo Laboratories Ltd, Greenford, Middlesex), Ampicillin Sodium and Carbenicillin Disodium (Beecham Research Laboratories, Betchworth, Surrey); all were of British Pharmacopoeial quality. The penicillin concentrations were based on an assumed $100 \%$ 
purity of the salts. The carbenicillin available at present may contain as much as $5 \%(\mathrm{w} / \mathrm{w})$ benzylpenicillin (British Pharmacopoeia I968); the material we used contained $4 \%(\mathrm{w} / \mathrm{w})$ of benzylpenicillin.

The following chromatographic solvent systems were used to identify the penicillin degradation products and the cell wall constituents:

I. The upper phase of butan-I-ol + acetic acid + water $(\mathrm{I} 2+3+5, \mathrm{v} / \mathrm{v})$;

2. Butan-I-ol + pyridine + water $(\mathrm{I}+\mathrm{I}+\mathrm{I}, \mathrm{v} / \mathrm{v})$ (Cole \& Sutherland, I966);

3. Chloroform + methanol + water $(65+25+4, \mathrm{v} / \mathrm{v})$;

4. Propan-2-ol + butanone + I N-hydrochloric acid $(60+\mathrm{I} 5+25, \mathrm{v} / \mathrm{v})$;

5. 2-Methylpropan-2-ol + butanone + propanone + methanol + water $+(0 \cdot 88)$ ammonia $(40+20+20+I+I 4+5, \mathrm{v} / \mathrm{v})$ (Haworth \& Heathcote, I969);

6. Ethyl acetate + pyridine + butan-I-ol $+n$-butyric acid + water $(\mathrm{IO}+\mathrm{IO}+5+\mathrm{I}+5, \mathrm{v} / \mathrm{v})$ (Mukerjee \& Ram, I964);

7. Ethyl acetate + pyridine + water + acetic acid $(5+5+3+\mathrm{I}, \mathrm{v} / \mathrm{v})$;

8. The upper phase of ethyl acetate + acetic acid + water $(3+\mathrm{I}+3, \mathrm{v} / \mathrm{v})$;

9. The upper phase of butan-I-ol +ethanol + water $+(0 \cdot 88)$ ammonia $(40+\mathrm{IO}+49+\mathrm{I}$, $\mathrm{v} / \mathrm{v})$;

10. Propan-I-ol $+(0 \cdot 88)$ ammonia + water $(6+3+\mathrm{I}, \mathrm{v} / \mathrm{v})($ Ellwood, Keleman \& Baddiley, 1963).

The solvents were of 'Analar' grade except for 2-methyl propan-2-ol and $n$-butyric acid which were 'Laboratory Reagent' grade (British Drug Houses Chemicals Ltd, Godalming, Surrey).

The amino acids, amino sugars, carbohydrates and phospholipids were chromatographically homogenous (British Drug Houses Chemicals Ltd, and Koch-Light Laboratories, Colnbrook, Buckinghamshire).

Strains and growth conditions. The strains of Pseudomonas aeruginosa used were NCTC 8203, NCTC 10490, 69/3425 and 69/4992; the two latter carbenicillin-resistant strains were kindly supplied by Dr E. J. L. Lowbury of the Birmingham Accident Hospital. The minimum inhibitory concentrations of carbenicillin and of benzylpenicillin against these organisms were determined using twofold serial dilutions of the antibiotics in nutrient broth; one $\mathrm{ml}$ amounts of these were inoculated with one drop ( $10^{5}$ organisms) of an overnight broth culture. After incubation overnight at $30^{\circ}$ the tubes were inspected visually and the lowest antibiotic concentration to cause complete inhibition of growth was considered to be the minimum inhibitory concentration. Habituation of strain NCTC I0490 to the penicillins was made by serial transfer in nutrient broth containing increasing subinhibitory concentrations; final concentrations of benzylpenicillin $\left(7.5 \mathrm{mg} / \mathrm{ml} ; 2.107 \times 10^{-2} \mathrm{M}\right)$ and carbenicillin $\left(0.1 \mathrm{mg} / \mathrm{ml} ; 2.367 \times 10^{-4} \mathrm{M}\right)$ were tolerated by substrains which are here designated RB and RC respectively. Strain NCTC 8203 was grown in the presence of benzylpenicillin $\left(5 \mathrm{mg} / \mathrm{ml} ; \mathrm{I} \cdot 404 \times 10^{-2} \mathrm{M}\right)$ to increase the yield of $\beta$-lactamase. The nutrient broth had the following composition $(\% \mathrm{w} / \mathrm{v})$ : peptone 0.6 ; pancreatic digest of casein, 0.4 ; yeast extract, 0.3 ; beef extract, 0.15 and glucose, 0.1 , adjusted to $\mathrm{pH} 7.0$.

The organisms used for metabolic and chemical investigations were grown as batches of $\mathrm{I} \cdot 2 \mathrm{l}$, in $4 \mathrm{l}$ conical flasks, shaken at $30^{\circ}$ for $\mathrm{I} 8 \mathrm{~h}$. Morphological examination of the suspensions, which usually contained $\mathrm{r} \cdot 0$ to $\mathrm{I} \cdot 3 \times 10^{8}$ viable organisms per $\mathrm{ml}$, was by phasecontrast microscopy. The organisms were collected by centrifugating at $2075 \mathrm{~g}$ for $2 \mathrm{~h}$ at $4^{\circ}$ and were washed three times with distilled water. The culture supernatants were tested for $\beta$-lactamase activity; in addition the antibiotic containing supernatants were biologically assayed and examined for the degradation products of benzylpenicillin and of carbenicillin. 
The concentrated bacterial suspensions after disruption at 175 (atm) with a Hughes press, were diluted with distilled water and centrifuged at $12,000 \mathrm{~g}$ for $30 \mathrm{~min}$. The supernatant, which contained some particulate material, was freeze-dried and stored at $-20^{\circ}$. The residue, which consisted of cell wall debris, was washed three times with distilled water and retained as a freeze-dried powder at $-20^{\circ}$.

Examination of culture supernatants. All the culture supernatants were examined for $\beta$-lactamase activity by incubating with benzylpenicillin $\left(2 \cdot 806 \times 10^{-3} \mathrm{M}\right)$ or carbenicillin $\left(2.367 \times 10^{-3} \mathrm{M}\right)$ for $60 \mathrm{~min}$ at $35^{\circ}$. Samples ( $\left.\mu \mathrm{l}\right)$ of each reaction mixture and the appropriate control solutions were examined for the penicillin and its corresponding penicilloic acid by agarose-starch gel electrophoresis. The gel was prepared from agarose $\mathrm{I} \%(\mathrm{w} / \mathrm{v})$ and hydrolysed starch $\mathrm{I} \%(\mathrm{w} / \mathrm{v})$ in a phosphate buffer, $\mathrm{pH} 7 \cdot 0$, ionic strength 0.02 . A potential of $2 \mathrm{~V} \mathrm{~mm}^{-1}$ was applied across the gel for $30 \mathrm{~min}$ when the penicillins and penicilloic acids were detected with iodine vapour (Thomas \& Broadbridge, I970). The antibiotic containing supernatants were examined for penicillin degradation products by chromatography using Whatman paper no. I and solvent systems I and 2 as described by Cole \& Sutherland (I966) and by electrophoresis as above. The residual antibiotic activity was estimated biologically. Since the assay organism used, Bacillus subtilis NCTC 8236 , is some sixty times more sensitive to benzylpenicillin than to carbenicillin, trace amounts of benzylpenicillin had first to be separated. The assay of both antibiotics in the carbenicillin containing supernatants was performed after thin-layer electrophoresis (Lightbown \& De Rossi, I965).

Examination of bacterial supernatants. Freeze-dried material $(200 \mathrm{mg})$ was dissolved in water, applied to a Sephadex G-25 column and eluted with 0.02 M-sodium acetate buffer, pH 7.6 (Sabath, Jago \& Abraham, 1965). The fractions having $\beta$-lactamase activity were collected and freeze-dried. The potency of an enzyme preparation and its Michaelis constant for benzylpenicillin were determined by potentiometric titration (Wise \& Twigg, I950) using a pH-stat (Radiometer, Copenhagen, Denmark). The enzyme solution, adjusted to $\mathrm{pH} 7 \cdot 0$ with $0.0 \mathrm{I} \mathrm{M}-\mathrm{KOH}$, was contained in a temperature-controlled polystyrene vessel maintained at $30^{\circ}$, and a steady stream of helium was passed over the reaction mixture. The substrate, benzylpenicillin $\left(2 \cdot 806 \times 10^{-4} \mathrm{M}\right)$, was added and the rate of hydrolysis monitored by measuring the alkali required to maintain the $\mathrm{pH}$ at $7 \cdot 0$. These precautions were necessary to maintain the blank at $\mathrm{pH} 7 \cdot 0$ for a period of an hour without the addition of even minute amounts of alkali; by this means a sharp end-point was obtained even with the low concentration of benzylpenicillin and carbenicillin used. The hydrolysis of carbenicillin and the effect of the $\beta$-lactamase inhibitors, cloxacillin and $p$-chloromeribenzoate ( $p$-CMB) were evaluated potentiometrically; it was necessary to maintain the $\mathrm{pH}$ at 8.0 in the case of $p$-CMB. Substrate profiles for certain enzyme preparations were obtained by comparing the constant, steady-state rates of hydrolysis of ampicillin, carbenicillin and cephaloridine relative to benzylpenicillin. The rate of hydrolysis of ampicillin at $\mathrm{pH} 7.8$ was determined by potentiometric titration whilst the formation of aminobenzylpenicilloic acid was confirmed by gel electrophoresis and by an increased absorption at $340 \mathrm{~nm}$. Enzymatic cleavage of the $\beta$-lactam bond of cephaloridine was measured as the decrease in absorption at $255 \mathrm{~nm}$ at $\mathrm{pH} 7 \cdot 0$.

As the enzyme preparations could not be adequately resolved by agarose-starch gel electrophoresis further characterization was achieved by isoelectric focusing in thin layers of polyacrylamide gel. The following solutions were used to prepare the gel. Acrylamide solution: acrylamide, $6.86 \mathrm{~g} ; N$ - $N^{1}$-methylenebisacrylamide, $0 . \mathrm{I} 8 \mathrm{~g}$; and water to $100 \mathrm{ml}$. Catalyst solution: $N, N, N^{1}, N^{1}$-tetramethylenediamine, $0.06 \mathrm{ml}$; riboflavin, I.06 $\mathrm{mg}$ and water to $100 \mathrm{ml}$. The chemicals were 'Laboratory Reagent' grade (British Drug Houses 
Chemicals Ltd), the carrier ampholyte pH range 3 to Io was supplied as a $40 \%$ solution (LKB Produckter A.B., Croydon, Surrey).

A polyacrylamide gel containing carrier ampholytes was prepared immediately before use by mixing $90 \mathrm{ml}$ of acrylamide solution with $30 \mathrm{ml}$ of catalyst solution and $\mathrm{I} 2 \mathrm{ml}$ of carrier ampholyte solution. This was sufficient for three $28 \times 13 \mathrm{~cm}$ plates which were prepared by the method of Humphreys (1970). Solutions of the samples, $50 \mu \mathrm{g}$ in $5 \mu \mathrm{l}$, were applied to the gel over an area $2.0 \mathrm{~cm}$ long and $\mathrm{I} \cdot 0 \mathrm{~cm}$ wide; the samples were spaced $2.0 \mathrm{~cm}$ from the edge of the plate and $1.5 \mathrm{~cm}$ apart. Electrical contact was made by inverting the plate so that the gel rested in a horizontal plane across two carbon rods $(20 \times 1 \cdot 25 \mathrm{~cm})$ $20 \mathrm{~cm}$ apart. Before use the cathode was moistened with $5 \%(\mathrm{v} / \mathrm{v})$ ethylenediamine and the anode with $5 \%(\mathrm{v} / \mathrm{v})$ phosphoric acid. Isoelectric focusing was performed in a humid chamber at $4^{\circ}$ by applying $400 \mathrm{~V}\left(2 \mathrm{~V} \mathrm{~mm}^{-1}\right)$ from a constant voltage supply for $\mathrm{I} 6 \mathrm{~h}$. The initial current was $5 \mathrm{~mA}$ which steadily decreased to $0.6 \mathrm{~mA}$ as the $\mathrm{pH}$ gradient of the carrier ampholytes was established in the gel. The $\mathrm{pH}$ gradient was measured at $\mathrm{I} \mathrm{cm}$ intervals along the gel with a glass surface electrode (type GM 23, Electronic Instruments Ltd, Richmond, Surrey).

The gel was stained for proteins with a solution of $0.2 \mathrm{~g}$ bromophenol blue, $50 \mathrm{ml}$ ethanol, $5 \mathrm{ml}$ glacial acetic acid and water to $100 \mathrm{ml}$ for $\mathrm{I} \mathrm{h}$. The above solution without the bromophenol blue was used for decolorizing the gel.

The $\beta$-lactamase activity was located by biological development. The gel was overlayered with a slab of assay agar, medium A, $\mathrm{pH} 7 \cdot 0$ (British Pharmacopoeia, 1968), inoculated with a spore suspension of Bacillus subtilis NCTC 8236 and contained one of the following: ampicillin, $8.07 \times 10^{-5} \mathrm{M}$; benzylpenicillin, $2.80 \times \mathrm{IO}^{-6} \mathrm{M}$; carbencillin, $7.10 \times \mathrm{IO}^{-5} \mathrm{M}$ or cephaloridine, $2.40 \times 10^{-6} \mathrm{M}$. The overlayered gel was incubated at $35^{\circ}$ for $\mathrm{I} 2 \mathrm{~h}$, zones of exhibition indicated the destruction of the antibiotic.

Examination of cell wall material. The loosely bound lipids of the cell wall were extracted under nitrogen with chloroform + methanol $(2+I, v / v)$, as described by Wilkinson (I968). The amount of lipid extracted was determined gravimetrically from both the dry weights of the lipid extract and the weight change of the residual cell wall. The lipid extract was separated into two fractions, free fatty acids and phospholipids, by acetone precipitation using the method described by Bobo \& Eagon (I968), gravimetric determinations were made on both fractions. All materials were dried to constant weight in vacuum over phosphorus pentoxide.

The phospholipid fractions were compared by chromatography on silica gel G using solvent system 3. Iodine vapour, ninhydrin, a modified sulphuric acid spray (Ziminski \& Borowski, 1966) and a molybdenum spray (Dittmer \& Lester, 1964) were used to detect the spots.

The cell wall preparations were hydrolysed by heating at $100^{\circ}$ with $\mathrm{HCl}$ both for $2 \mathrm{~h}$ with I $\mathrm{N}$ and for $20 \mathrm{~h}$ with $6 \mathrm{~N}$ and examined for amino acids, amino sugars and carbohydrates. Amino acids were identified by two-dimensional thin-layer chromatography on cellulose plates using solvent systems 4 followed by 5 (Haworth \& Heathcote, 1969), the spots were detected with ninhydrin/cadmium acetate reagent. Descending paper chromatography on Whatman no. 4 previously washed with $2 \mathrm{~N}$-acetic acid and rinsed with distilled water employing solvent systems 6 and 7 was used to identity the amino sugars; the spots were detected with alkaline silver nitrate. Carbohydrates were detected by descending paper chromatography as above using solvent systems 7 and 9 and by ascending paper chromatography with Whatman no. 4 using solvent systems 8 and Io. Spots were detected with alkaline silver nitrate, aniline hydrogen phthalate, ninhydrin or Schiff's periodate reagent. 
The phosphorus content of the cell walls was determined using the modified method of Allen (1940). To estimate the cations, the cell walls (200 mg) were digested with $10 \mathrm{ml} 60 \%$ $(\mathrm{w} / \mathrm{v})$ perchloric acid at $150^{\circ}$. The solutions were evaporated to $2 \mathrm{ml}$ and then made up to Io $\mathrm{ml}$ with distilled water. The resulting solutions were analysed using an atomic absorption spectrophotometer (Perkin Elmer 303).

\section{RESULTS}

Growth of the organisms. Pseudomonas aeruginosa NCTC 10490 and its two antibiotic habituated substrains (RB and RC) were grown in antibiotic-free nutrient broth producing cultures designated ( $\mathrm{RB} / \mathrm{O}$ and $\mathrm{RC} / \mathrm{O}$ ) they were also grown in nutrient broth containing the corresponding penicillins producing cultures designated ( $\mathrm{RB} / \mathrm{B}$ and $\mathrm{RC} / \mathrm{C}$ ). The different cultures are indicated in Table $\mathrm{I}$ together with the final $\mathrm{pH}$ of each culture. Filamentous forms, characteristically produced by penicillin, were present in the substrains of $P$. aeruginosa NCTC I0490 which had been cultured in the presence of either benzylpenicillin or carbenicillin. Impairment of cell wall synthesis was not evident amongst cells of the carbenicillin resistant strain, 69/4992, grown in the presence of carbenicillin. The minimum inhibitory concentrations of benzylpenicillin and of carbenicillin against the strains of $P$. aeruginosa are shown in Table 2. The substrains of $P$. aeruginosa NCTC I0490 habituated to benzylpenicillin and to carbenicillin reverted to sensitivity to these antibiotics on repeated subculture in antibiotic free media.

Residual penicillin content and $\beta$-lactamase activity of the culture supernatants. Examination of the supernatants from cultures grown in the presence of antibiotics showed that

Table I. The growth conditions used for the strains of Pseudomonas aeruginosa and the presence $(+)$ or absence $(-)$ of $\beta$-lactamase activity in the resulting culture supernatants

\begin{tabular}{|c|c|c|c|c|c|}
\hline \multirow[b]{3}{*}{$\begin{array}{c}\text { Strain of } \\
P . \text { aeruginosa }\end{array}$} & \multicolumn{2}{|c|}{ Growth conditions } & \multirow{3}{*}{$\begin{array}{c}\text { Laboratory } \\
\text { designation } \\
\text { of I } 8 \mathrm{~h} \\
\text { culture }\end{array}$} & \multirow{2}{*}{\multicolumn{2}{|c|}{$\beta$-lactamase activity against }} \\
\hline & \multirow{2}{*}{$\begin{array}{c}\text { Antibiotic } \\
\text { concentration } \\
\times 10^{-3} \mathrm{M}\end{array}$} & \multirow[b]{2}{*}{$\begin{array}{c}\mathrm{pH} \text { after } \\
\text { incubation }\end{array}$} & & & \\
\hline & & & & benzylpenicillin & carbenicillin \\
\hline NCTC 10490 & None & $7 \cdot 18$ & $\mathbf{S}$ & - & - \\
\hline NCTC $10490 / R B$ & None & $7 \cdot 19$ & $\mathrm{RB} / \mathrm{O}$ & - & - \\
\hline NCTC $10490 / R B$ & Benzylpenicillin $21 \cdot 07$ & $6 \cdot 40$ & $\mathrm{RB} / \mathrm{B}$ & + & - \\
\hline NCTC $10490 / R C$ & None & $7 \cdot \mathrm{II}$ & $\mathrm{RC} / \mathrm{O}$ & - & - \\
\hline NCTC $10490 / R C$ & Carbenicillin 0.24 & $7 \cdot 09$ & $\mathrm{RC} / \mathrm{C}$ & + & - \\
\hline $69 / 4992$ & None & $7 \cdot 14$ & $4992 / 0$ & + & + \\
\hline $69 / 4992$ & Carbenicillin $4 \cdot 73$ & $7 \cdot 12$ & $4992 / \mathrm{C}$ & + & + \\
\hline
\end{tabular}

$\mathbf{R B}$ indicates strain habituated to benzylpenicillin, $\mathrm{RC}$ to carbenicillin.

Table 2. Minimum inhibitory concentrations of benzylpenicillin and carbenicillin against Pseudomonas aeruginosa determined using twofold serial dilution in nutrient broth

$\begin{array}{lrr}\quad \begin{array}{c}\text { Strain of } \\ P . \text { aeruginosa }\end{array} & \begin{array}{c}\text { Benzylpenicillin } \\ (\mu \mathrm{g} / \mathrm{ml})\end{array} & \begin{array}{c}\text { Carbenicillin } \\ (\mu \mathrm{g} / \mathrm{ml}\end{array} \\ \text { NCTC } 10490 & \mathrm{I}, 000 & 2 \\ \text { NCTC } 10490 / \mathrm{RB} & >\mathrm{I} 6,000 & 800 \\ \text { NCTC } 10490 / \mathrm{RC} & >\mathrm{I} 6,000 & 800 \\ \text { NCTC } 8203 & 8,000 & 4 \\ 69 / 4992 & >\mathrm{I} 6,000 & 8,020 \\ 69 / 3425 & >16,000 & 8,000\end{array}$


benzylpenicillin had been completely hydrolysed by Pseudomonas aeruginosa NCTC I0490, habituated to benzylpenicillin. Two acid degradation products were detected by thin-layer gel electrophoresis, corresponding to benzylpenicilloic acid and benzylpenicillin. Paper chromatography showed the second product corresponded with a prepared sample of benzylpenilloic acid (Mozingo \& Folkers, 1949), the decarboxylation product of benzylpenicilloic acid. In acid solution benzylpenicilloic acid will be decarboxylated (Schwartz, 1969) though the exact mechanism has not been studied. By monitoring the optical rotation of the enzymatic hydrolysis of benzylpenicillin this second reaction can be seen to proceed at a much slower rate than the hydrolytic reaction (unpublished observation). Only the benzylpenicillin present in the carbenicillin containing supernatant had been hydrolysed by the carbenicillin habituated strain of $P$. aeruginosa NCTC I0490, there was no significant decrease in the potency of the carbenicillin itself. By contrast $P$. aeruginos $a$ 69/4992 degraded both penicillins to their respective penicilloic acids (Table I).

$\beta$-Lactamase activity of the cell supernatants. The potencies of the different enzyme preparations, expressed as units of penicillinase as defined by Pollock \& Torriani (1953), are shown in Table 3, together with their Michaelis constant for benzylpenicillin. The rates of hydrolysis, obtained under steady-state conditions, when the enzyme was saturated, for ampicillin, carbenicillin or cephaloridine are shown relative to benzylpenicillin. All the enzyme preparations obtained from the strains of Pseudomonas aeruginosa NCTC 10490 were completely inactivated by cloxacillin $\left(2.0 \times 10^{-4} \mathrm{M}\right)$; in the presence of carbenicillin $(5.0 \times$ $\left.10^{-4} \mathrm{M}\right)$ activity of the enzymes was reduced by $50 \% ; p$-CMB $\left(5^{\circ} 0 \times 10^{-4} \mathrm{M}\right)$ caused no inhibition. The hydrolysis of benzylpenicillin or of carbenicillin by the $\beta$-lactamase of 69/4992 was completely inhibited by cloxacillin $\left(5^{\circ} \circ \times 10^{-4} \mathrm{M}\right), p-\mathrm{CMB}\left(5^{\circ} \circ \times 10^{-4} \mathrm{M}\right)$ had no inhibitory effect.

Isoelectric focusing resolved the total soluble proteins of the enzyme preparations within the range of $\mathrm{pH} 4 \cdot 0$ to $6 \cdot 8$. Subsequent protein staining did not reveal any marked differences between any of the preparations but biological development differentiated two distinct groups of active material, each of which had an isoelectric focusing pattern which was complex (Fig. I). Enzyme preparations from the same strain had identical isoelectric focussing patterns when developed on different substrates, even when the bacteria were grown in differing environments. Because the substrate profiles of the $\beta$-lactamase of strain NCTC I0490 and 69/4992 resembled respectively those described for Pseudomonas aeruginosa NCrC 8203 (Sabath et al. 1965) and P. aeruginosa 69/3425 (Sykes \& Richmond, 1970),

Table 3. Comparison of the $\beta$-lactamase preparations from Pseudomonas aeruginosa, potency (penicillinase units/mg) and Michaelis constant $\left(K_{m}\right)$ determined against benzylpenicillin $2.8058 \times 10^{-4} \mathrm{M}$ and the maximum rates of hydrolysis of ampicillin, carbenicillin and cephaloridine at stated concentration relative to benzylpenicillin (100)

\begin{tabular}{|c|c|c|c|c|c|}
\hline \multirow[b]{2}{*}{ Preparation } & \multirow[b]{2}{*}{$\begin{array}{l}\text { Penicillinase } \\
\text { (units/mg) }\end{array}$} & \multirow{2}{*}{$\begin{array}{c}\text { Michaelis } \\
\text { constant for } \\
\text { benzylpenicillin } \\
\left(\mathrm{IO}^{-5} \mathrm{M}\right)\end{array}$} & \multicolumn{3}{|c|}{ Maximum rates of hydrolysis } \\
\hline & & & $\begin{array}{c}\text { Ampicillin } \\
2.69 \times 10^{-4} \mathrm{M}\end{array}$ & $\begin{array}{l}\text { Carbenicillin } \\
2.37 \times 10^{-4} \mathrm{M}\end{array}$ & $\begin{array}{c}\text { Cephaloridine } \\
2 \cdot 4 \mathrm{I} \times \mathrm{IO}^{-4} \mathrm{M}\end{array}$ \\
\hline $\mathbf{S}$ & 0 & 0 & . & . & . \\
\hline $\mathrm{RB} / \mathrm{O}$ & 100 & 3.005 & . & . & . \\
\hline $\mathrm{RB} / \mathrm{B}$ & 430 & $2 \cdot 952$ & 23 & 0 & 995 \\
\hline $\mathrm{RC} / \mathrm{O}$ & 370 & $2 \cdot 952$ & . & . & . \\
\hline $\mathrm{RC} / \mathrm{C}$ & 400 & 3.025 & 25 & 0 & 915 \\
\hline $4992 / 0$ & 1420 & $2 \cdot 935$ & II I & 13 & 96 \\
\hline $4992 / \mathrm{C}$ & 1020 & $2 \cdot 922$ & I 13 & 9 & IO4 \\
\hline
\end{tabular}



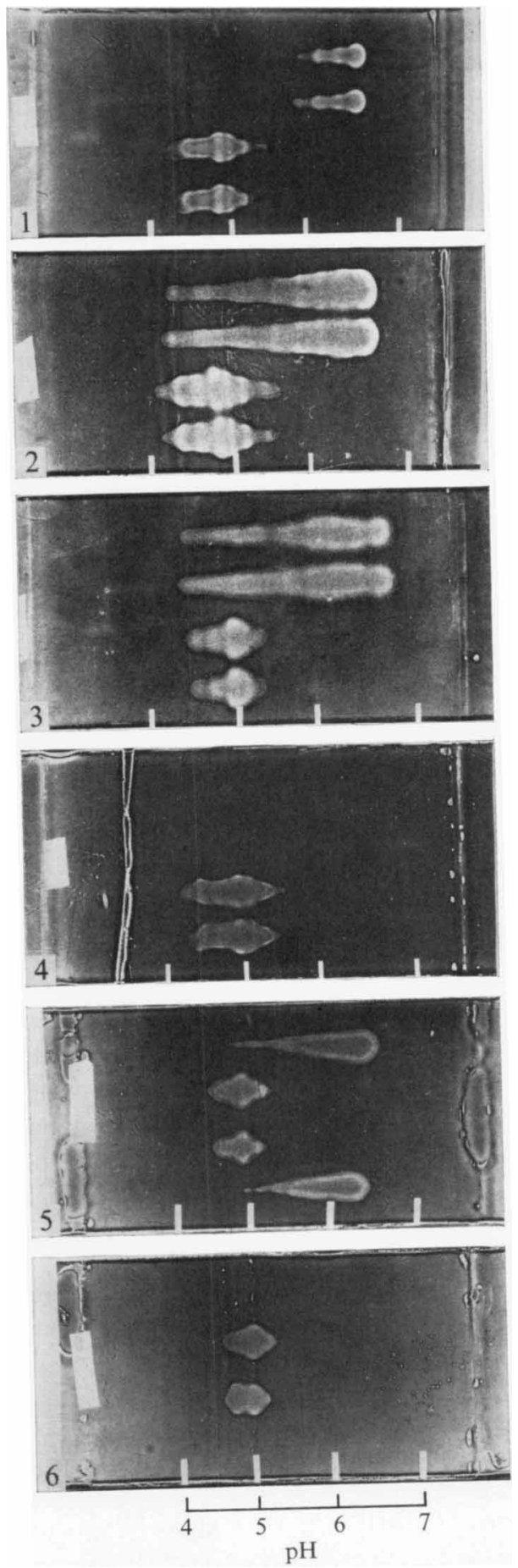

Isoeletric focusing, using $\mathrm{pH} 3$ to Io carrier ampholytes, of $\beta$-lactamase preparations synthesized by strains of Pseudomonas aeruginosa grown in nutrient broth containing different penicillins.

Fig. I to 4. Preparations top to bottom: NCTC 10490 (benzylpenicillin, $21 \cdot 07 \times 10^{-3} \mathrm{M}$ ); NCTC 10490 (carbenicillin, $0.24 \times 10^{-3} \mathrm{M}$ ); 69/4992, (o) and 69/4992 (carbenicillin, $4.73 \times 1 \mathrm{I}^{-3} \mathrm{M}$ ). Development was on assay agar seeded with Bacillus subtilis NCTC 8236 containing ampicillin, $3 \mu \mathrm{g} / \mathrm{ml}$ (Fig. I); benzylpenicillin, $0.2 \mu \mathrm{g} / \mathrm{ml}$ (Fig. 2); cephaloridine, $0 . \mathrm{I} \mu \mathrm{g} / \mathrm{ml}$ (Fig. 3) and carbenicillin, 3.0 $\mu \mathrm{g} / \mathrm{ml}$ (Fig. 4).

Fig. 5, 6. Preparations top to bottom: NCTC I0490 (benzylpenicillin, $\left.2 \times \cdot 07 \times 10^{-3} \mathrm{M}\right) ; 69 / 4992(0)$; $69 / 3425$ (O); NCTC 8203 (benzylpenicillin, $14.04 \times 10^{-3} \mathrm{M}$ ). Development as above; benzylpenicillin, $0.2 \mu \mathrm{g} / \mathrm{ml}$ (Fig 5) and carbenicillin, 3.0 $\mu \mathrm{g} / \mathrm{ml}$ (Fig. 6). 
enzyme preparations from these strains were compared by isoelectric focusing. The isoelectric focusing pattern of strains NCTC 10490 and NCTC 8203 were similar though the major component of the latter enzyme had an isoelectric point at $\mathrm{pH} 6.5$ compared with the former at $\mathrm{pH} 6 \cdot 6$. The $\beta$-lactamases from the two carbenicillin-resistant strains $69 / 4992$ and $69 / 3425$ were very similar to each other except that the latter enzyme contained a greater proportion of material with an isoelectric point of $\mathrm{pH} 4.4$.

Composition of the cell walls. The amount of readily extractable lipids from the different batches of Pseudomonas aeruginosa NCTC I0490 varied from I4.6\% to $19.2 \%$ of the dry weight of the cell walls. The greater proportion of the lipids consisted of free fatty acids and neutral lipids, the residue was made up of phospholipids (Table 4).

The phospholipids were separated into four distinct components by thin-layer chromatography. The main component was tentatively identified as phosphatidyl ethanolamine, the remaining three spots corresponding to disphosphatidyl glycerol, phosphatidyl glycerol and phosphatidyl choline though the true identity of the latter is doubtful (Bobo \& Eagon, I968; Hancock \& Meadow, 1969). There were no qualitative differences in the phospholipid fraction from any of the cell wall preparations.

Chromatographic examination of the different cell wall acid hydrolysates revealed no qualitative nor quantitative differences in composition. The principal compounds detected were $\mathrm{N}$-acetyl glucosamine, muramic acid, alanine, glutamic acid, 2,4-diaminopimelic acid, asparagine and glutamine. Determination of the cell wall content of cations and phosphorus showed no significant differences (Table 4).

\section{DISCUSSION}

The very stringent precautions used in the $\beta$-lactamase assays enable the hydrolysis of very small quantities of penicillin to be monitored. It is significant that with such a sensitive method the hydrolysis of carbenicillin was not detected when examining the enzyme preparation from Pseudomonas aeruginosa NCTC 10490. In the presence of either benzylpenicillin or carbenicillin this strain of pseudomonas produces a $\beta$-lactamase though neither whole bacteria nor enzyme preparations inactivate carbenicillin. Both carbenicillin and cloxacillin inhibit the activity of this $\beta$-lactamase which suggests that carbenicillin has some affinity for the enzyme though it is resistant to hydrolysis.

The presence of filamentous cells amongst the cultures of Pseudomonas aeruginosa NCTC I0490 which had grown in contact with carbenicillin indicates that this penicillin impairs cell wall formation as does higher concentrations of benzylpenicillin. No gross differences were detected in the composition of the cell wall of the sensitive and penicillin habituated strains of NCTC I0490. The cell walls of the penicillin habituated strains contained slightly more readily extractable lipid, phosphorus, $\mathrm{Ca}^{2+}, \mathrm{Mg}^{2+}$ and $\mathrm{Na}^{+}$than the

Table 4. Comparison of the cell walls of Pseudomonas aeruginosa NCTC I0490 grown in the presence of benzylpenicillin $2 \mathrm{I} \cdot 07 \times 10^{-3} \mathrm{M}, \mathrm{RB} / \mathrm{B}$ and carbenicillin $0.24 \times 10^{-3} \mathrm{M}, \mathrm{RC} / \mathrm{C}$

Expressed as percentage $(w / w)$ of cell wall dry weight.

\begin{tabular}{|c|c|c|c|c|c|c|c|c|c|}
\hline Cell wall & REL & NL & PL & $\mathrm{Ca}^{2+}$ & $\mathrm{Mg}^{2+}$ & $\mathrm{Zn}^{2+}$ & $\mathrm{Na}^{+}$ & $\mathbf{K}^{+}$ & $\mathbf{P}^{\bar{a}}+$ \\
\hline $\mathrm{s}$ & $14 \cdot 5$ & $9 \cdot 46$ & $4 \cdot 06$ & 0.23 & 0.38 & 0.004 & 0.029 & 0.0015 & $I \cdot I 6$ \\
\hline $\mathrm{RB} / \mathrm{B}$ & 15.9 & I I $\cdot 00$ & $4 \cdot 28$ & 0.33 & 0.58 & 0.004 & 0.043 & 0.0009 & $I \cdot 28$ \\
\hline $\mathrm{RC} / \mathrm{C}$ & $19 \cdot 2$ & I 2.56 & $5 \cdot 13$ & 0.30 & 0.44 & 0.005 & 0.040 & 0.0006 & $\mathrm{I} \cdot 80$ \\
\hline
\end{tabular}

Readily extractable lipids (REL), free fatty acids and neutral lipids (NL) and phospholipids (PL). $\mathrm{s}$, Control no antibiotic. 
sensitive strain. The overall cell wall composition of $P$. aeruginosa NCTC I0490 is similar to that reported for the cell walls of $P$. aeruginosa oso-64 (Bobo \& Eagon, I968) and a polymyxin sensitive strain of $P$. aeruginosa NCTC 6750. An increase in the readily extractable lipid content of the cell walls of NCTC $675^{\circ}$ has been associated with polymyxin resistance (Brown $\&$ Watkins, 1970). No difference has been detected between the mucopeptide content of the cell walls of penicillin-sensitive and penicillin-resistant staphylococci (Rogers \& Jeljaszewicz, I96I ; Dyke, 1969) though there is a report that the cell walls of penicillin-resistant staphylococci contain a higher proportion of readily extractable lipids (Dunnick \& O'Leary, 1970).

Garber \& Friedman (1970) described a $\beta$-lactamase obtained from Pseudomonas aeruginosa 1978 whose substrate profile, especially the lack of activity against carbenicillin, was similar to that of $P$. aeruginosa NCTC 10490 . They suggested that the intrinsic resistance of the pseudomonads was an important factor in penicillin resistance. The carbenicillin resistance of $P$. aeruginosa NCTC 10490 habituated to carbenicillin is not due to the $\beta$ lactamase but it may be attributed to an increase in the lipid content of the cell walls. This is in accord with reports of a carbenicillin-resistant $P$. aeruginosa which did not hydrolyse carbenicillin (Brumfitt et al. 1967; Smith \& Finland, 1968; Watanakunakorn, Phair \& Hamburger, 1970) even when the bacteria produced a diffusible $\beta$-lactamase (Jones \& Lowbury, 1967). A permeability barrier which limits the access of certain penicillins into the cell is a feature of Gram-negative penicillinase producing bacteria and this barrier has been implicated in penicillin resistance (Smith, Hamilton-Miller \& Knox, 1969). Our results suggest that the readily extractable lipids may be required for such a barrier.

The high degree of carbenicillin resistance exhibited by Pseudomonas aeruginosa 69/4992 can be attributed to the rapid destruction of the antibiotic by the constitutive $\beta$-lactamase of this organism, which was not inhibited by cloxacillin. Similarly, Neu \& Swarz (1969) recorded that methicillin did not allow carbenicillin to exert its antibacterial effect against resistant strains of Escherichia coli and $P$. aeruginosa.

The enzymes obtained from Pseudomonas aeruginosa were differentiated into two categories by the method of isoelectric focusing. Enzymes that hydrolysed carbenicillin formed one category and those enzymes not active against carbenicillin were in the second category. Genetic transfer of $\beta$-lactamase activity has been shown to be mediated amongst pseudomonads by extrachromosomal R-factors (Fullbrook, Elson \& Slocombe, 1970; Sykes $\&$ Richmond, 1970). Therefore it was anticipated that the $\beta$-lactamases able to hydrolyse carbenicillin would be similar, if not identical, as the strains 69/3425 and 69/4992 which produced these enzymes were isolated in the same hospital unit. The similarity of the substrate profiles of the enzymes from $P$. aeruginosa NCTC I0490 and NCTC 8203 indicated that they too were related to each other.

The isoelectric point reflects the total composition of the charge amino acids but the exact distribution of the charge residues will affect the isoelectric focusing position. The complex isoelectric focusing patterns exhibited by both categories of $\beta$-lactamase are an expression of this type of variation. This complex composition of the $\beta$-lactamase enzyme has not been reported and if confirmed it will complicate the study of $\beta$-lactamase kinetics. Using starch gel electrophoresis, Jack \& Richmond (1970) noted the presence of two distinct $\beta$-lactamases in a strain of Escherichia coli; such heterogeneity may be explained by a single charge difference.

The hydrolytic activities of the neutral $\beta$-lactamases produced by Pseudomonas aeruginosa NCTC 8203 and NCTC 10490 for different penicillins are related to the degree of the hydrophobic nature of these antibiotics i.e. (cephaloridine $>$ benzylpenicillin $>$ ampicillin). The least hydrophobic antibiotic, carbenicillin, is not hydrolysed although the enzyme inhibitory 
activities of carbenicillin and cloxacillin suggest that this category of enzymes must associate in some way with both hydrophilic and hydrophobic penicillins. The basic enzymes from $P$. aeruginosa $69 / 3425$ and $69 / 4992$ both hydrolyse carbenicillin, though less rapidly than other antibiotics tested. This type of enzyme could be responsible for the marked carbenicillin resistance exhibited by these strains of $P$. aeruginosa.

We are grateful to Mr R. A. Blows for assistance with the atomic absorption spectrometry and to Mr J. W. Lightbown for helpful discussion.

\section{REFERENCES}

Acred, P., Brown, D. M., Knudsen, E. T., Rolinson, G. N. \& Sutherland, R. (1967). New semisynthetic penicillin active against Pseudomonas pyocyanea. Nature, London 215, 25-30.

Allen, R. J. L. (1940). The estimation of phosphorus. Biochemical Journal 34, 858-865.

Bell, S. M. \& SMrth, D. D. (1969). Resistance of Pseudomonas aeruginosa to carbenicillin. Lancet i, 753-754.

Bово, R. A. \& EAGON, R. G. (1968). Lipids of cell walls of Pseudomonas aeruginosa and Brucella abortus. Canadian Journal of Microbiology 14, 503-513.

British Pharmacopoeia (1968). Addendum (1969). London: The Pharmaceutical Press.

BRown, M. R. W. \& WATKINS, W. M. (I970). Low magnesium and phospholipid content of cell walls of Pseudomonas aeruginosa resistant to polymyxin. Nature, London 227, I360-1361.

Brumfitt, W., Percival, A. \& Leigh, D. A. (I967). Clinical and laboratory studies with Carbenicillin. Lancet i, I289-I 293.

Cole, M. \& Sutherla ND, R. (1966). The role of penicillin acylase in the resistance of Gram-negative bacteria to penicillins. Journal of General Microbiology 42, 345-356.

Darrell, J. H. \& Waterworth, P. M. (1969). Carbenicillin resistance in Pseudomonas aeruginosa from clinical material. British Medical Journal 3, I4I-I43.

DitTMER, J. C. \& LesteR, R. L. (1964). A simple specific spray for the detection of phospholipids on thinlayer chromatograms. Journal of Lipid Research 5, 126.

DunNick, J. K. \& O'Leary, W. M. (1970). Correlation of bacterial lipid composition with antibiotic resistance. Journal of Bacteriology 1or, 892-900.

DYKE, K. G. H. (1969). Penicillinase production and intrinsic resistance to penicillin in methicillin-resistant cultures of Staphylococcus aureus. Journal of Medical Microbiology 2, 26I-278.

Ellwood, D. C., Keleman, M. V. \& Baddiley, J. (I963). The glycerol teichoic acid from the walls of Staphylococcus albus NTCC 7944. Biochemical Journal 86, 213-225.

Fullbrook, P. D., Elson, S. W. \& Slocombe, B. (1970). R-factor mediated $\beta$-lactamase in Pseudomonas aeruginosa. Nature, London 226, 1054-1056.

Garber, N. \& Friedman, J. (I970). $\beta$-Lactamase and the resistance of $P_{\text {seudomonas aeruginosa }}$ to various penicillins and cephalosporins. Journal of General Microbiology 64, 343-352.

Hancock, I. C. \& Meadow, P. M. (I969). The extractable lipids of Pseudomonas aeruginosa. Biochimica et biophysica acta 187, 366-379.

Haworth, C. \& HeAthCote, J. G. (1969). An improved technique for the analysis of amino acids and related compounds on thin-layers of cellulose. I. Qualitative separation. Journal of Chromatography $4 \mathrm{I}$, 380-385.

HUMPHREYs, K. C. (1970). Isoelectric focusing of Trypanosoma brucei subgroup antigens in polyacrylamide gel thin layers. Journal of Chromatography 49, 503-510.

JACK, G. W. \& RICHMOND, M. H. (1970). A comparative study of eight distinct $\beta$-lactamases synthesized by Gram-negative bacteria. Journal of General Microbiology 6r, 43-6I.

Jones, R. J. \& Lowbury, E. J. L. (1967). Prophylaxis and therapy for Pseudomonas aeruginosa infection with carbenicillin and with gentamicin. British Medical Journal iii, 79-82.

KNudsen, E. T., Rolinson, G. N. \& SutherLand, R. (I967). Carbenicillin: A new semi-synthetic penicillin active against Pseudomonas pyocyanea. British Medical Journal iii, 75-78.

LightBown, J. W. \& DE Rossi, P. (1965). The identification and assay of mixtures of antibiotics by electrophoresis in agar gel. Analyst 9o, 89-98.

Lowbury, E. J. L., Kidson, A., Lilly, H. A., Ayliffe, G. A. J. \& Jones, R. J. (1969). Sensitivity of Pseudomonas aeruginosa to antibiotics: emergence of strains highly resistant to carbenicillin. Lancet ii, 448-452. 
Mozingo, R. \& Folkers, K. (1949). In The Chemistry of Penicillin, p. 563. Edited by H. T. Clark, J. R. Johnson \& R. Robinson. Princeton, New Jersey: University Press.

MukeRJEe, H. \& RAM, J. S. (I964). Paper chromatographic separation of glucosamine and galactosamine. Analytical Biochemistry 8, 393-394.

Neu, H. C. \& Swarz, H. (1969). Resistance of Escherichia coli and Salmonella typhimurium to carbenicillin. Journal of General Microbiology 58, 30I-305.

Newson, S. W. B. (1969). Carbenicillin-resistant Pseudomonas aeruginosa (correspondence). Lancet ii, I I4I.

Pollock, M. R. \& ToRrianI, A-M. (1953). The purification and characteristics (physico-chemico) of the penicillinase of Bacillus cereus. Compte rendu des séances de l'Académie des sciences 237, 276-278.

Richardson, A. E., Spittle, C. R., James, K. W. \& Robinson, O. P. W. (1968). Experiences with carbenicillin in the treatment of septicaemia and meningitis. Postgraduate Medical Journal 44, 844-847.

Rogers, J. J. \& JELJASZEWICZ, J. (196I). Inhibition of the biosynthesis of cell mucopeptides by the penicillins. A study of a penicillin-sensitive Staphylococcus aureus and a penicillin-resistant Staphylococcus aureus. Biochemical Journal 81, 576-584.

Sabath, L. D., JaGo, M. \& Abraham, E. P. (1965). Cephalosporinase and penicillinase activities of a $\beta$-lactamase from Pseudomonas aeruginosa. Biochemical Journal 96, 739-752.

Schwartz, M. A. (1969). Chemical aspects of penicillin allergy. Journal of Pharmaceutical Sciences 58, 643-66I.

SMith, C. B. \& FinLand, M. (1968). Carbenicillin: activity in vitro and absorption and excretion in normal young men. Applied Microbiology 16, I753-1760.

Smith, J. T., Hamilton-MilleR, J. M. T. \& KNox, R. (I969). Bacterial resistance to penicillins and cephalosporins. Journal of Pharmacy and Pharmacology 21, 337-358.

StepHenson, J. B. P. (I969). Resistance of Pseudomonas aeruginosa to carbenicillin (correspondence). Lancet $\mathbf{i}$, I098-1099.

Stratrord, B. C. (I968). The treatment of infections due to Pseudomonas aeruginosa with carbenicillin. Medical Journal of Australia 2, 890-895.

SYKes, R. B. \& RICHMOND, M. H. (I970). Intergeneric transfer of a $\beta$-lactamase gene between $P$. aeruginosa and E. coli. Nature, London 226, 952-954.

Thomas, A. H. \& BRoAdbridge, R. A. (1970). Electrophoretic separation of penicillins and penicilloic acids. Analyst 95, 459-462.

Watanakunakorn, C., Phatr, J. P. \& Hamburger, M. (1970). Increased resistance of Pseudomonas aeruginosa to carbenicillin after reversion from spheroplast to rod form. Infection \& Immunity $\mathbf{I}$, 427-430.

WIL KINSON, S. G. (1968). Studies on the cell walls of Pseudomonas species resistant to ethylenediaminetetraacetic acid. Journal of General Microbiology 54, 195-213.

WISE, W. S. \& TWIGG, G. H. (1950). Determination of penicillinase activity. Analyst 75, 106-108.

ZIMINSKI, T. \& BOROWSKI, E. (1966). A new spray reagent replacing sulphuric acid in thin-layer chromatography. Journal of Chromatography 23, 480. 